"An analysis on the factors affecting profitability level of Sharia banking in Indonesia"

\begin{tabular}{|c|c|}
\hline AUTHORS & $\begin{array}{l}\text { Muhammad Said (D https://orcid.org/0000-0002-4716-9327 } \\
\text { Herni Ali }\end{array}$ \\
\hline ARTICLE INFO & $\begin{array}{l}\text { Muhammad Said and Herni Ali (2016). An analysis on the factors affecting } \\
\text { profitability level of Sharia banking in Indonesia. Banks and Bank Systems, } \\
\text { 11(3), 28-36. doi:10.21511/bbs.11(3).2016.03 }\end{array}$ \\
\hline DOI & http://dx.doi.org/10.21511/bbs.11(3).2016.03 \\
\hline RELEASED ON & Wednesday, 12 October 2016 \\
\hline JOURNAL & "Banks and Bank Systems" \\
\hline FOUNDER & LLC "Consulting Publishing Company "Business Perspectives" \\
\hline & $\begin{array}{l}= \pm= \\
= \pm=\end{array}$ \\
\hline NUMBER OF REFERENCES & NUMBER OF FIGURES \\
\hline
\end{tabular}

(C) The author(s) 2023. This publication is an open access article. 
Muhammad Said (Indonesia), Herni Ali (Indonesia)

\title{
An analysis on the factors affecting profitability level of Sharia banking in Indonesia
}

\begin{abstract}
The purpose of this research is to analyze the influence of Capital Adequacy Ratio (CAR) Third Party Funds (TPF), Non Performing Financing (NPF), Financing to Deposit Ratio (FDR), Operation Cost Operating Income (OCOI), Net Operating Margin (NOM), Gross Domestic Product (GDP), inflation and Return on Asset (ROA) as a proxy of Islamic bank's profitability in Indonesia during 2011-2014 periods. The population of study was Sharia banking (BS) in Indonesia. Time series data from Indonesian Banking Statistics 2011-2014 were used as the primary data. Multiple linear regression was applied as method of analysis. The result shows that CAR, NPF, FDR and NOM did not affect profitability, while TPF, OCOI had negative effect on profitability. Meanwhile, GDP and inflation variable had significant effect with positive direction.
\end{abstract}

Keywords: Sharia bank, ROA, TPF, NPF and inflation. JEL Classification: G21, E31.

\section{Introduction}

In the last decade, Islamic banking and finance or Sharia bank grow very significantly throughout the world (Outlook Global Islamic Economy, 2016) both in the countries with majority Muslim population and in western countries with majority nonMuslim population (Saeed, 2006; Said, 2014). The growth in the global industry is broadly measured by the quantity and value of Islamic finance assets. In 2011, there were more than 300 Islamic financial institutions operating in more than 75 countries worldwide (Hassan and Saleh, 2011; Taylor, 2003; Ganadian \& Gosmawi, 2004; Ar Roubaie et al., 2010). Currently, Islamic financial institutions evolve throughout world (Perry V and Rehman, 2011; di Moura, 2013; Abdullah and Chee, 2010; al Jayyiousi, 2012). The 2015 report on Islamic banking and Financial Development states that the world's total Sharia financial assets were \$2 trillion, with Islamic banking representing 73 percent of these (OGIE, 2016).

Indonesia as the country with which Muslim population number is the largest in the world should be the center of Sharia economic and financial development. The fact of matters as indicated by the Global Islamic Financial Report (GIFR, 2014), Indonesia occupies the fourth position among other countries with total asset US\$ 35,65 billion. It occupies the top ninth position in the world.

In national scope, Otoritas Jasa Keangan (Financial Service Authority) reported that per May 2015, the total asset of Indonesian Sharia banking has reached IDR 278.91 trillion with marketplace of $4.67 \%$. The asset value of Islamic banking and finance is still

(C) Muhammad Said, Herni Ali, 2016.

Muhammad Said, Faculty of Economics and Business State Islamic University Syarif Hidayatullah Jakarta, Indonesia.

Herni Ali, Faculty of Economics and Business State Islamic University Syarif Hidayatullah Jakarta, Indonesia.

small compared to the national banking (GIFR, 2015). Statistic data on the growth rate of Sharia bank during 2010-2014 show that the percentage growth rate of Sharia bank is still better than that of conventional one thought its growth rate tends to decrease. Detail comparison on the growth rate between Islamic and conventional bank can be seen in the following table.

Table 1. Growth rate of conventional and Sharia banking

\begin{tabular}{|c|c|c|}
\hline \multirow{2}{*}{ Year } & \multicolumn{2}{|c|}{ Growth (\%) } \\
\cline { 2 - 3 } & Conventional banking & Sharia banking \\
\hline 2010 & 18.78 & 46.98 \\
\hline 2011 & 21.41 & 48.61 \\
\hline 2012 & 16.75 & 34.05 \\
\hline 2013 & 16.21 & 24.23 \\
\hline 2014 & 13.38 & 12.42 \\
\hline
\end{tabular}

Source: Indonesian Banking Statistics (processed).

The growth rate of banking is determined by many factors. According to the note of the prior researches, the bank's ability of maintaining competitiveness and of yielding profitability as the most important indicator to measure a bank's performance is one of the determinant factors. Ranianti and Ratnawati (2014) focused their work on Third Party Fund and Non Performing Financing on Return on Asset (ROA) in Sharia bank. Riyadi and Yulianto (2014) studied the effect of profit sharing finance, trading finance, and FDR and NPF on the profitability of Sharia commercial bank in Indonesia. Wibowo and Syaichu (2013) pictured the effect of interest rate, inflation, CAR and NPF on the profitability of Sharia bank found that interest rate, inflation, CAR and NPF do not affect to return of asset (Khasawneh et al., 2014; Silvia Hendrayanti, 2013; Margaretha and Zai, 2013; Sabir et. al., 2012; Ali et al., 2011; Moh. Akabar and Nor Hayati, 2011; Dennis Olson and Taisier A. Zoubi, 2011; Sukarno and Syaichu, 2006. 
Though the growth of Islamic banking and finance has attracted a great deal of enthusiasm of the researchers, but it has also been subject to a number of other criticisms which one is its inability to get away from the trappings of conventional banks (Wilson, 1999; Tlemsani and Matthews, 2009; Isam and Matthews, 2009; Kingstone, 2009).

The main goal of the current research was to analyze the effect of capacity of adequacy ratio, third party fund, non-performing loan, inflation and profit sharing rate on the profitability of Sharia bank in Indonesia.

\section{Literature review}

1.1. Islamic banking and finance in nature. Islamic banking and finance have reached a successful and unprecedented expansion among Muslims all over the world during the last few years. Not only is the high growth rate astonishing of the Islamic banking and finance, but also many conventional banks just converted (Akkizidis and Khandelwal, 2007). These two kinds of banks are different in principles and doing the same functions as the mediary financial institution. Islamic banking and finance is claimed free of interest, while the conventional banking is using interest as a time factor for borrowed money (Taib, Ramayah and Razak, 2008). Islamic banking and finance is also lighted by the Sharia values, ethics and universal moral philosophy (Robin and Reidenbac, 1987). It integrates religious and cultural values with the specific goals of Shariah (maqashidasysyari'ah) such as the wisdom and welfare of the people both in this world and hereafter as well (Chapra, 1985, p. 33; Abdullah and Chee, 2010; Saeed, 1996; al Joyyiousi, 2012).

The experts defined Islamic banking and finance as the finance must not purchase equity in or provide credit to product and activities prohibited by religion such as riba and gharar (Pitluck, 2012, p. 433). IBF refers to financial institution that performs Islamic transaction derived from either Islamic law or Islamic economic theory (Ahmed, 2007), but it performs conventional banking services such as checking account, savings accounts and loans (Ahmed, 2007, p. 4). It reconciles a secular financial system with the basic tenets of the Islamic faith (Mauro, 2013, p. 11) and integrates material and spiritual well-being at once and emphasizes economic justice and cooperation (Nik Hassan, 2012, p. 96).

1.2. Principles of Islamic banking and finance. The principles of Islamic finance are derived from the Qur'an and the Sunnah. Both the resources dictate that paying interest is prohibited. First principle is to avoid interest, IF formulates its own instruments that are different from the conventional which creates exposure to the real sector and must have efficient risk management. The second principle is to involve the profit and loss sharing system. Parties to the financial transaction must share both the risk and the rewards that may be attached to it. In this way, excessive losses and profits are minimized in order to gain a maximal profit. The third principle is the prohibition of uncertainty or speculation and demand using asset-backing, tangible and or identifiable underlying asset and remain connected to the real economy (Di mouri, 2013, p. 11; Pitluck Aaron, 2012, p. 433; Abdullah and Chee, 2010, p. 45).

As a business offers its products and services to its clients, IBF has some instruments which are designed to be applied in the Islamic finance businesses in order to service both Muslim and non-Muslim community that may seek its products and service. IBF endeavors to provide Sharia compliant products and services to the customers. It balances the moral and material needs of society in achieving the socio-economic justice (Farooq, Ahmad and Jamil, 2010; Ramayah and Razak, 2008). Generally, it has instruments which consist of fourth different divisions that are gratuitous contracts, trading contracts, investment contracts and supporting contracts (Miniaoui and Gohou, 2011).

There are some principles underlying the Islamic banking and finance. First, Islamic banking and finance (IBF) system is built on fundamental principles that the life of human being depends on material sources as the media provided by God to meet their needs, b) Islam orders investment and prohibits monopoly or evoking wealth, c) investment conducted in such a way that could ensure the fulfillment of basic needs, d) the prohibition of riba, e) Zakat is an essential element of Islamic economy system, f) economic system depends on a firm and rooted moral standard in Islamic social system concerning what forbidden and fault (Haron and Azmi, 2009). Second, commerce and trading are free from usury, gharar (fraud) and speculation. Thirdly, economy as a part of all aspects of life is originating from tauhid (unity of God) principle (Wilson, 1997).

\section{Research methodology}

2.1. Data sources and technics of analysis. This research applied time series data obtained during 20102014 as the main data sources with the main focus to be analyzed CAR, ROA, TPF, NPF, FDR, NOM, OCOI, GDP and inflation. The data were analyzed using statistic descriptive and classical assumption tests, and hypotheses testing was carried out using a multiple regression model with the equation below:

$$
\begin{aligned}
& R O A=\alpha+\beta_{1} C A R+\beta 2 D P K+\beta_{3} N P F+\beta_{4} F D R+ \\
& +\beta_{5} B O P O+\beta_{6} N O M+\beta_{7} G D P+\beta_{8} \text { Inflation }+ \\
& + \text { Interest } \beta_{9} \times e .
\end{aligned}
$$

Hypotheses testing was carried out using statistic test considering the result of multiple regression equation established above, including:

- $R^{2}$ (coefficient of determinant) test, measuring the model's ability of explaining dependent variable 
variation, with the following criteria of $\mathrm{R}^{2}$ values: very low $(0.000-0.199)$, low $(0.20-0.399)$, moderate $(0.40-0.599)$, strong $(0.60-0.799)$ and very strong $(0.80-1.000)$. Meanwhile, for the multipleregression model with more than two independent variables, Adjusted $\mathrm{R}^{2}$ was used as coefficient of determinant (Gazali, 2009; Santoso, 2001).

- $T$-test (partial test)

$T$-test or partial test or individual test was used to see the effect of independent variable individually (partially) on dependent variable. Similar to $F$-test carried out by considering significance value, it was conducted with the same stipulation: when significance value > 0.05 , Ho is supported and $\mathrm{H} 1$ is not supported, meaning that there is no simultaneous effect. Meanwhile, when significance value $<0.05$, Ho is not supported and $\mathrm{H} 1$ is supported meaning that there is a partial effect.

\section{- $F$-test (simultaneous test)}

Simultaneous statistic test or $F$-test was used to indicate whether or not all of independent variables in the model affect simultaneously the dependent one. The test was carried out by considering significance value, with the following stipulation: when significance value $>0.05$, Ho is supported and $H 1$ is not supported, meaning that there is no simultaneous effect. Meanwhile, when significance value $<0.05$, Ho is not supported and $\mathrm{H} 1$ is supported meaning that there is a simultaneous effect.

\section{Operational definition of variables}

The research consisted of two variables, dependent and independent with the detail of operational definition as follows:

\section{a. Dependent variable}

\section{Return on Asset (ROA)}

It is the proxy on a bank's profitability measure. This ratio suggests the bank's ability in managing asset it has to yield profit. It is calculated with the formula below:

\section{ROA $=$ EBIT $/$ Total Assets}

\section{b. Independent variable}

- Capital Adequacy Ratio (CAR)

It is the ratio used to measure the bank's capital ability in compensating the potential loss in loaning activity and other security trading. This ratio is obtained with the following formula: CAR = Equity Capital / Total Loan

- Third Party Fund (TPF)
It is the customers' saving in the form of savings, clearing account, and deposit in rupiah and foreign currency collected by Sharia bank in certain period of time, representing in billion rupiahs (Andraeny, 2011).

- Non-Performing Financing (NPF)

NPF is the ratio of non-performing financing to total financing distributed by Sharia bank, and represented in percentage rupiahs (Andraeny, 2011). Its formula can be seen below:

$\mathrm{NPF}=$ Non-Performing Financing $/$ Total Assets

- Financing to Deposit Ratio (FDR)

Similarly to CAR, Financing to Deposit Ratio (FDR) is the proxy of bank's liquidity showing the bank's ability in repaying the obligation of customers that have invested their fund. This ratio is calculated with the following formula:

FDR $=$ Total Asset $/$ Total Deposit

- Net Operating Margin (NOM)

It is the proxy for the bank's profitability. This ratio is obtained with the following formula:

NIM = Net Income $/$ Total Assets

- Operating Cost and Operating Income (OCOI) It is the ratio proxied to represent the efficiency of banking. The smaller the OCOI ratio value, the better is the efficiency of banking. This ratio is obtained with the formula below: $\mathrm{COI}=$ Operating Cost/Operating Income

- Gross Domestic Product (GDP)

GDP is used to find out the economic condition of a state. This variable is measured using real GDP obtained from BPS from January 2010 to December 2013. It is expressed in billions.

- Inflation

Inflation is an increase of total price in an economy. This variable is measured by recording the inflation rate of national consumer price index published monthly by BI from January 2010December 2013. Its unit is percentage.

\section{Analysis and discussion}

- Normality test

Normality test is carried out to find out whether or not data are distributed normally. This test is conducted by considering the $p$-plot chart and using Kolmogorov Smirnov test. Result of test found that the data have been distributed normally which indicated by the points in the chart spreading around or close to diagonal line or its $p$-plot line, and KS test obtains significance value $>0.05$ for all variables, so that the data are not distributed normally. 


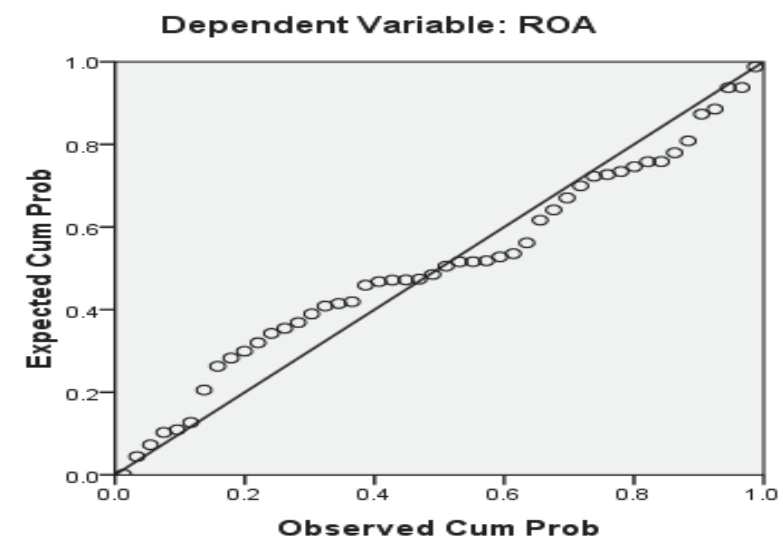

Source: data processed with SPSS.

Fig. 1. Normality test with $p$-plot chart

Table 2. Normality test with KS

\begin{tabular}{|c|c|c|}
\hline & & Unstandardized residual \\
\hline \multicolumn{2}{|l|}{$N$} & 48 \\
\hline \multirow{2}{*}{ Normal parametersa } & Mean & .0000000 \\
\hline & Std. Deviation & .17213601 \\
\hline \multirow{3}{*}{ Most extreme differences } & Absolute & .097 \\
\hline & Positive & .085 \\
\hline & Negative & -.097 \\
\hline \multicolumn{2}{|l|}{ Kolmogorov-Smirnov Z } & .672 \\
\hline \multicolumn{2}{|l|}{ Asymp. Sig. (2-tailed) } & .758 \\
\hline
\end{tabular}

Source: data are processed with SPSS.

a. The result of test found that the data have been distributed normally. It can be seen from the points in the chart spreading around or close to diagonal line or its $P$-plot line, and KS test obtains significance value $>0.05$ for all variables, so that the data are not distributed normally.

b. Heteroscedasticity c. This test is conducted to find out whether or not there is variance or residual difference between one observation and another in the regression model established. This test is carried out by considering the pattern apparent in the scatter plot. Based on the result of test, it can find out the points in the chart in which they are distributed randomly and do not form certain pattern.

Scatterplot

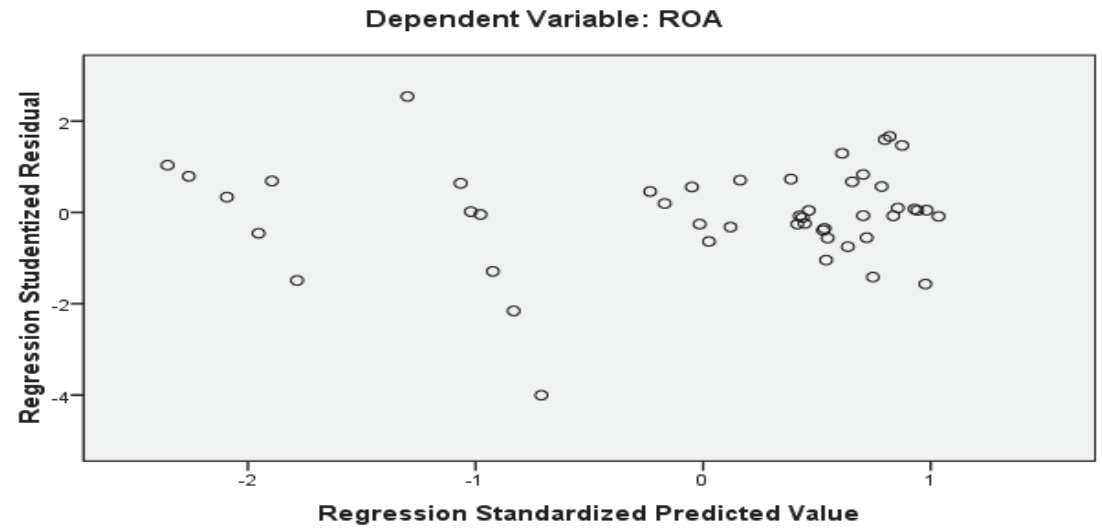

Source: data are processed with SPSS.

Fig. 2. Heteroscedasticity test 
This test is carried out by considering the size of tolerance and variance inflation factor (VIF). Considering the result of test, it can be found that for each of variables, the tolerance value $>0.10$ and variance inflation factor $(\mathrm{VIF})$ value $<10$.

Table 3. INSERT THE TITLE

\begin{tabular}{|l|l|c|c|}
\hline & & \multicolumn{2}{|c|}{ Collinearity statistics } \\
\hline \multirow{7}{*}{1} & (Constant) & Tolerance & VIF \\
\cline { 2 - 4 } & CAR & .574 & 1.742 \\
\cline { 2 - 4 } & DPK & .393 & 2.546 \\
\cline { 2 - 4 } & NPF & .133 & 7.505 \\
\hline \multirow{7}{*}{} & FDR & .103 & 9.745 \\
\cline { 2 - 4 } & BOPO & .722 & 1.385 \\
\cline { 2 - 4 } & NOM & .563 & 1.777 \\
\cline { 2 - 4 } & GDP & .558 & 1.791 \\
\cline { 2 - 4 } & INFLASI & .588 & 1.701 \\
\cline { 2 - 4 } & INTEREST & .071 & 14.122 \\
\hline
\end{tabular}

Source: data are processed with SPSS.

The result above shows that one variable is indicated as having multicolinearity symptom, but in this research, the variable remains to be included into variable with limited data, so that it can be said that there is no problem with the regression model constructed.

\section{c. Autocorrelation}

This test was conducted to see whether or not there is a correlation between confounding error in t period and that in previous period. The good regression model is the one independent of autocorrelation symptom. For this test, Durbin-Watson (DW) test is carried out with the criterion that when $\mathrm{d}<4-\mathrm{dl}$, there is no autocorrelation symptom. Or, according to Wahid Sulaiman (2004), the criterion is as follows: when $1.65<\mathrm{DW}<2.35$, there is no autocorrelation; when $0.21<\mathrm{DW}<1.65$, it cannot be inferred and when DW $<1.21$, there is autocorrelation symptom. Considering the result of test with SPSS, it can be found DW value of 1.360 , meaning that autocorrelation cannot be inferred when the criterion is base on Wahid Sulaiman (2004).

Table 4. Autocorrelation test

\begin{tabular}{|c|}
\hline Durbin-Watson \\
\hline 1.360 \\
\hline
\end{tabular}

Source: data are processed with SPSS.

\section{Coefficient of determinacy $\left(R^{2}\right)$}

Having conducted classical assumption test finding that the data and regression model is independent of normality, heteroscedasticity and multicolinearity problems, the next is conducted, that is, hypotheses testing consisting of coefficient of determinacy $(R$ square test), $T$-test (partial) and $F$-test (simultaneous).

Table 5. Coefficient of determinacy test

\begin{tabular}{|c|c|c|c|c|}
\hline Model & $R$ & $R$ square & Adjusted $R$ square & Std. Error of the estimate \\
\hline 1 & $.937^{\mathrm{a}}$ & .878 & .849 & .1914383 \\
\hline
\end{tabular}

Source: data are processed with SPSS.

Considering the Table 5 above, coefficient of correlation $(\mathrm{R})$ coefficient of determinacy ( $\mathrm{R}$ square) and adjusted coefficient of determinacy (adjusted $\mathrm{R}$ square) values can be found. Based on the adjusted $\mathrm{R}$ square value of 0.878 , it can be stated that the variables of research including CAR, Third Party Fund (DPK), NPF, FDR, BOPO, NOM, GDP, inflation, and Loan Interest rate explain $87.8 \%$ of the Indonesian Sharia banking profitability variable, while the rest is explained by other factors or variables excluded from this research, including, among others, return on financing, rupiah exchange rate, etc.

4.1. $F$-statistic test (simultaneous equation). Fstatistic or simultaneous test is used to see and to examine whether or not independent variables in the research affect simultaneously the dependent variable. It is because the model is said as good when $F$-test is significant. Therefore, before conducting partial or $T$ test, simultaneous or $F$-test should be conducted first, as illustrated in Table 6.

Table 6. Simultaneous equation test

\begin{tabular}{|l|l|c|c|c|c|c|}
\hline \multicolumn{7}{|c|}{ ANOVAb } \\
\hline \multirow{3}{*}{1} & Model & Sum of Squares & df & Mean Square & $\mathrm{F}$ & Sig. \\
\cline { 2 - 8 } & Regression & 9.995 & 9 & 1.111 & 30.302 & $.000^{\mathrm{a}}$ \\
\cline { 2 - 8 } & Residual & 1.393 & 38 & .037 & & \\
\cline { 2 - 7 } & Total & 11.387 & 47 & & & \\
\hline
\end{tabular}

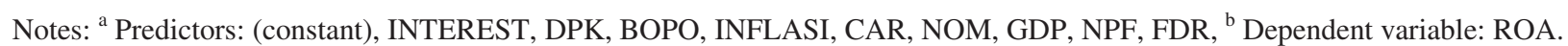
Source: data are processed with SPSS. 


\section{Hypotheses analysis and discussion}

5.1. First hypothesis (H1). 5.1.1. H1: Capital Adequacy Ratio (CAR) affects positively the profitability of Sharia banking. Based on Table 3.6, the coefficient value of 0.025 is obtained for CAR, and significance value for DPK is 0.315 meaning that it is larger than alpha $(\alpha)$ of 0.05 . It means that Capital Adequacy Ratio (CAR) does not affect positively the profitability of Sharia banking in Indonesia with positive direction of relation. The result of research suggests that every one unit increase in CAR of some banking does not certainly impact on the increase in ROA of bank. Thus, $\mathrm{H}_{1}$ can be supported or not be supported.

The result of research supports Edi Satrio and Muhammad Syaichu's (2013) study finding that CAR does not affect ROA. It indicates that the size of bank's asset (CAR) uncertainly affects the size of bank's profitability. In the bank with large asset, but with no ability of using its asset effectively to yield profitability, the asset will not affect significantly the profitability of bank. In the presence of Sharia bank's attempt of maintaining asset adequacy, the bank cannot issue their fund easily for funding, because it can generate big risk.
Mona Abdullah (2009) in EdhiSatrio (2013) stated that Capital Adequacy Ratio cannot affect the bank's ROA. It shows that at least $8 \%$ of CAR size that should be met by bank does not exert belief and secure feeling effect on the public so that CAR $8 \%$ is only intended by Indonesian banks to meet the preconditions of internal banking. The public's trust is due to the presence of government's insurance over the fund they save in bank. Thus, CAR ratio perhaps does not affect the profitability of bank.

In addition to the two explanation above, CAR does not affect the profitability of bank, because the increase in CAR is not compensated with the increase in productive asset, but the increase of CAR in Sharia banking such as subsidiary office opening is accompanied with the increase in non-productive asset number or the increase in problematic financing, so that it even gives the bank the negative result, because the bank's cash flow becomes not optimal; therefore, the profitability of bank is not good. Considering the data of research as shown in Figure 3 in the period of 2014, NPF level of Sharia banking in Indonesia increases compared with that in previous years; it is that likely makes the result of current research insignificant.

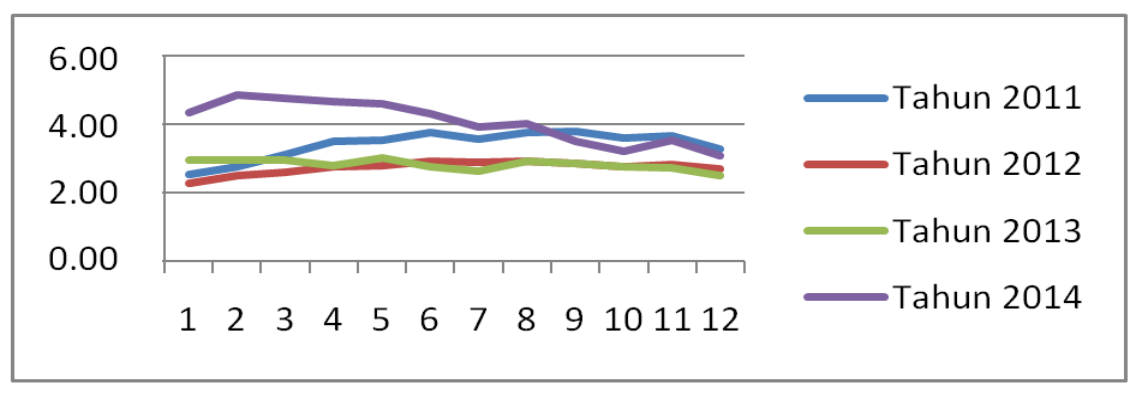

Fig. 3. Chart of problematic financing in 2011-2014

5.1.2. Second hypothesis $\left(\mathrm{H}_{2}\right)$. $\mathrm{H}_{2}$ : Third Party Fund (DPK) affects positively the profitability of Sharia banking. Table 6 shows that significance (sig.) value is 0.000 and coefficient value is -0.005115 . It indicates that Third Party Fund (DPK) affects the profitability of Sharia banking. But, considering the coefficient value obtained, the result suggest that the relationship between two of them is negative, meaning that the increase in the third party fund instead results in the lowered profitability of bank. This result is in contradiction with the hypothesis. Thus, $\mathrm{H}_{2}$ is not supported.

The result of research is in contradiction with the hypothesis developed, in which the higher the marketplace of third party fund, the higher is the loan given. The increase in loan capacity results in the increased interest income revenue, so that the bank's profit increases as well (Sinungan, 2000 in Edhi Satrio and Muhammad Syaichu, 2013).

However, the result of current research is in line with Sukma (2009) finding that the third party fund
(DPK) affects negatively the ROA. It means that the total third party fund will decrease the profitability of Sharia banking. The appearance of negative sign in the simultaneous result for DPK may be due to the less maximal distribution of third party fund to financing thereby not getting profit from its financing activity.

5.2. Third hypothesis $\left(\mathbf{H}_{3}\right), H_{3}$ : Non-Performing Financing (NPF) affects negatively the profitability of Sharia bank. Considering the data processing shown in Table 6, coefficient value of -0.042 is obtained for NPK with significance value of 0.717 larger than alpha $(\alpha)$ of 0.05 . It means that nonperforming financing variable does not affect the profitability of Sharia banking. Thus, $\mathrm{H}_{3}$ is not supported.

This insignificant result is likely, because the data of NPF used in the research are not the one targeted by the bank management, but historical NPF that has occurred in research period. As the NPF targeted by management reflects on control level and financing 
policy to be implemented by the bank (Pratin, 2005). If the company targets a low NPF, it means that the bank management will apply the profit sharing financing distribution policy more tightly (cautiously). On the contrary, when the targeted NPF is larger, the distribution of profit sharing financing will be easier (looser). Thus, the policy taken will impact on the bank's profitability performance. Meanwhile, in this research, the data of NPF used is not the one targeted by the bank management. Thus, the bank's profitability performance in this study is not affected by non-performing financing (NPF) factor, as explained above.

\subsection{Fourth hypothesis $\left(\mathbf{H}_{\mathbf{4}}\right) . \mathrm{H}_{4}$ : Financing Deposit} Ratio (FDR) affects positively the profitability of Sharia banking. Considering the Table 6 above, it can be found that the significance (sig.) value of 0.953 is larger than alpha $(\alpha)$ of 0.05 . It indicates that Financing Deposit Ratio (FDR) fund does not affect the profitability of Sharia banking. This result is in contradiction with the hypothesis, so that $\mathrm{H}_{4}$ is not supported.

Financing to Deposit Ratio (FDR) is ratio of financing distributed by bank to the third party fund successfully collected by Sharia general bank. The higher this ratio, the more effectively the Sharia bank distributes its finance. However, this successful ratio is highly dependent on the quality of financing distribution which means that although the amount of financing distribution is high, but if it is not accompanied with the low non-performing financing or NPF, it would not yield profitability to the bank; instead, it will bring loss to the bank. The result of current research shows that the financing distribution conducted does not affect considerably the profitability of Sharia bank.

This result is consistent with the result in the second hypothesis finding that Third Party Fund (DPK) does not affect the profitability of Sharia general bank. It is because the distribution of third party fund is less maximal to financing so that the bank does not get profit from its financing activity (Sukma, 2009).

5.4. Fifth hypothesis $\left(\mathbf{H}_{5}\right) . H_{5}:$ BOPO affects negatively the profitability of Sharia banking. Considering the data processing shown in Table 6 , it can be found that the coefficient of -0.026 for BOPO and significance value of 0.02 are smaller than alpha $(\alpha)$ of 0.05 ; thus, from this research it can be seen that BOPO variable affects the profitability of Sharia banking with negative direction of relation, meaning that the higher the BOPO ratio, the less efficient is the bank leading to the decreased profitability of bank. Thus, $\mathrm{H}_{5}$ is supported.

The result of research is consistent with the hypothesis, indicating that the higher the financing load level of bank, the smaller is the profit the bank obtains. The high operating cost load of bank the bank should as- sume generally will be imposed to the income deriving from financing allocation. The higher loan load or cost will reduce the capital and profit the bank has. The result of current research is in line with that of studies conducted by EdhiSatrio and Muhammad Syaichu (2013), Yuliani (2007) and YacubAzwir (2006).

5.5. Sixth hypothesis $\left(\mathbf{H}_{6}\right) . H_{6}$ : Net Operating Margin (NOM) affects negatively the profitability of Sharia banking. Considering the Table 6 above, significance (sig.) value is obtained of 0.619 larger than alpha $(\alpha)$ of 0.05. It indicates that Net Operating Margin (NOM) does not affect the profitability of Sharia banking. This result was in contradiction with the hypothesis; thus, $\mathrm{H}_{6}$ was not supported.

Theoretically, the improvement of financing distribution to customers should improve the bank's income. NOM size indicates that operating income is subtracted with profit sharing fund and subtracted with operating cost is larger than the mean productive asset, so that the increase in profit sharing income over the mean productive asset the bank manages will increase the bank profitability. However, in fact, financing distribution to customers are not followed with the effective management of productive asset by bank; it can be seen from the high non-performing financing ratio, thus, the increase in NOM does not impact directly on the increased profitability of bank.

5.6. Seventh hypothesis $\left(\mathbf{H}_{7}\right)$. $H_{7}$ : Gross Domestic Product (GDP) affects negatively the profitability of Sharia bank. Considering the data processing shown in Table 3.6, it can be found the coefficient of 0.0001778 for GDP and significance value of 0.008 smaller than alpha $(\alpha)$ of 0.05 ; thus, from this research it can be seen that GDP variable affects the profitability of sharia banking with positive direction of relation, meaning that the higher the GDP ratio, the higher is the profitability ratio of Sharia banking. Thus, $\mathrm{H}_{7}$ is supported.

A country's economic growth (GDP) is closely related to welfare and prosperity its people can feel. Economic growth (GDP) becomes indicator of macroeconomics, as well can affect the profitability of bank; if GDP increases, the people's income would increase so that the saving ability would increase as well. This increased saving will affect the profitability of bank (SadonoSukirno, 2003). This theory is confirmed by the finding of a study conducted by Ali et al. (2011) on general and Sharia banks existing in Pakistan, the result of which concluded that Gross Domestic Product (GDP) has significant positive correlation with the amount of saving collected by bank in Pakistan.

5.7. Eighth hypothesis $\left(\mathbf{H}_{8}\right)$. $H_{8}$ : Inflation affects negatively the profitability of Sharia banking. Table 6 shows the coefficient value of 0.075 for inflation with significance value of 0.002 smaller than alpha $(\alpha)$ of 0.05 ; thus, from this current research, it can be found that inflation variable affects positively the profitability 
of Sharia banking. It means that if there is an increase in inflation rate, the profitability of Sharia bank in Indonesia would increase. It is in contradiction with the hypothesis stating that inflation affects the profitability with negative direction of relation. Thus, $\mathrm{H}_{8}$ is not supported.

The result of current research shows that instead, the increase in inflation rate occurring affects positively the performance of Sharia general bank; this study indicates that the increase in inflation will improve the profitability of Sharia bank. It is perhaps because basically the high inflation reflects on the increase in the goods' price occurring generally due to money circulation exceeding the volume of goods or to the increase in production cost. In such the condition, the government as regulator usually will issue a monetary policy to deal with inflation, one of which is disconto police, that is, to increase or to decrease the reference interest rate. As we know, the character of Sharia bank is to proscribe the presence of interest system and to allow (to legalize) the presence of profit sharing. This character likely avoids the Sharia bank from the effect of fluctuating interest rate. It means that when inflation occurs and government issues an interest rate policy, such the policy does not affect considerably the performance of Sharia banking. Even, inflation will result in deposit rate and the financing the Sharia bank makes will be higher. The increase in the portfolio of sharia general bank during inflation indicates the public's trust in Sharia bank's durability (survival) and the customers begin to recognize that Sharia bank would have larger durability and certainty during inflation.

\section{Conclusion and implication}

\section{Conclusion}

The result of hypothesis testing and discussion above, it can be concluded that Capital Adequacy Ratio
(CAR) does not affect the profitability of Sharia bank in Indonesia; Third Party Fund (TPF) affects negatively the profitability of Sharia bank; Non Performing Financing (NPF) does not affect the profitability of Sharia bank; Financing Deposit Ratio (FDR) does not affect the pro-fitability of Sharia bank; COOIC affects negatively the profitability of Sharia general bank in Indonesia; Net Operating Margin (NOM) does not affect the profitability of Sharia bank; Gross Domestic Product (GDP) affects positively the profitability of Sharia bank, and inflation affects positively the profitability of Sharia bank in Indonesia.

\section{Implication}

Based on the conclusion above, it is recommended to the management to increase the profitability of Sharia bank by issuing the operation cost operating income (OCOI) more selectively so that the bank's efficiency will improve and the ROA of bank as well. The bank should maintain its Capital Adequacy Ratio (CAR) at $8 \%$ corresponding to BI's regulation to maintain the public trust which will affect the health of bank as well. The bank should maintain the Sharia principle far away from usury (interest) principle. Thus, the change of interest rate will affect only slightly the profitability of sharia bank. In addition, the bank should distribute financing selectively to the public in order the NPF level can be suppressed to improve the profitability of bank.

Then, to other researcher needs to explore further and to expand the factors affecting the profitability of Sharia bank by adding macroeconomic variable, external factor, fundamental factor of banking, or Sharia banking character factor. It is also noteworthy to add risk variable as dependent variable to make the future research contributing more considerably.

\section{References}

1. Ahlgreen, N. \& Antell, J. (2009). Stock Market Lingkages and Financial Contagion: A Cobreaking Analysis, The Quartley Review of Economics and Finance in Sukmana, Raditya \& Kholid, M. (2012). Impact of Global Finance Crisis on Islamic and Conventional Stock in Emerging Market: An Application of Arch and Garch, Australian Journal of Islamic Banking and Finance, Vol. No. 2 Dec, 2012, pp. 17-29.

2. Akbar, Mohammad and Hayati Nor. (2011). Relationship Between Islamic Banking Profitability and Determinants of Efficiency, The IUP Journal of Managerial Economics, 9 (3).

3. Ali et al. (2011). Bank-Specific and Macroeconomic Indicators of Profitability - Empirical Evidence from the Commercial Banks of Pakistan, Pakistan: International Journal of Business and Social Science, 2 (6).

4. Al-Roubaie, Amer and Alvi, Shafiq (eds). (2010). Islamic Banking and Finance: Critical Concepts in Economic. Routledge: Avenue, New York.

5. Barry, Norman. (1991). The Morality of Business Enterprise. Aberden University Press: Farmers Hall, Aberden.

6. Bourkhis, K. \& Nabi, Mahmoud S. (2013).Islamic and Conventional Banks' Soundness during the 2007-2008 Financial Crisis, Review of Financial Economics.

7. Brennan, Geoffrey and Eusepei, Giusepp. (2009). The Economics Ethices and The Ethics of Economics Value, Markets and the State. Edward Elgar Publishing: Massachustts USA.

8. Cihák, Martin and Hesse1, Heiko. (2008). Islamic Banks and Financial Stability: An Empirical Analysis. International Monetary Fund. IMF Working Paper.

9. Di Moura, Flipo. (2013). Islamic Finance in Europe. Occasional Paper Series. June No. 244.

10. Said, Muhammad. (2014). Islamic Finance in Canada: Problems and Prospects. Germany: Lambert Academy Publishing 
11. Haron, Sudin and Azmi, Wan Nursafriza. (2009). Islamic Finance and Banking System Philosophies, Principles and Practices. McGraw Hill Education: Malaysiansdn.Bhd.

12. Hela Miniaoui and Gaston Gohou. (2011). International Conference on Management, Economics and Social Sciences (ICMESS'2011) Bangkok.

13. Hendrayanti, Silvia dan Muharam, Harjum. (2013). Analisis Pengaruh Faktor Internal dan Eksternal Terhadap Profitabilitas Perbankan (Studi Pada Bank Umum di Indonesia Januari Periode 2003- Februari 2012), Diponegoro Journal of Management, 2 (3).

14. Hilmi. (2006). Analisis Faktor-Faktor yang Mempengaruhi Pembiayaan Mudharabahpada Bank Syariah (studi kasus pada Bank Syariah Mandiri). Unpublished Thesis. Universitas Indonesia.

15. Ahmed, Karen. (2007). The Business of Culture: Morality and Practice In Islamic Finance. Dissertation. Unpublished, Chicago University Illinois.

16. Perry, J.F., Frederick, V. and Rehman. (2011). Scheherazade S. Globalization of Islamic Finance: Myth or Reality? International Journal of Humanities and Social Science, 1 (19), December.

17. Khasawneh, Ahmad Y. (2014). Risk and Profitability in Middle East and North Africa Banking System: An Examination of Off Balance Sheet Activities, International Journal of Business and Finance Research, 8 (3).

18. Olson, Dennis and A. Zoubi Taisier. (2011). Efficiency and Bank Profitability in MENA Countries. Emerging Markets Review, June 2011.

19. Outlook Global Islamic Economy. (2016). Thompson Reuters.

20. Ranianti, Atika dan Ratnawati, Nirdukita. (2014). PengaruhPembiayaan, Dana PihakKetigadan Non Performing Financing terhadap Return on Assets Perbankan Syariah di Indonesia 2009-2013: Penerapan Model Simultan, Jurnal Ekonomi Pembangunan, Vol. 1.

21. Riyadi, Slamet danYulianto, Agung. (2014). PengaruhPembiayaanBagiHasil, PembiayaanJualBeli, Financing to Deposit Ratio (FDR) dan Non Performing Financing (NPF) terhadapProfitabilitas Bank UmumSyariah Indonesia, Accounting Analysis Journal, 2014.

22. Rodoni, Ahmad dan Hamid, Abdul. (2008). Lembaga Keuangan Syariah. Zikrul Hakim: Jakarta.

23. Sabir, M, Muhet, Al. (2012). PengaruhRasioKesehatan Bank Terhadap Kinerja Keuangan Bank Umum Syariah dan Konvensional di Indonesia, Journal Analis, 1 (1) pp. 79-86.

24. Sadono Sukirno. (1998). PengantarTeoriMikroEkonomi. Jakarta: PT. SalembaEmpat.

25. Saeed, Abdullah. (1996). Islamic Banking And Interest: A Study Of The Prohibition of Riba And Its Contemporary Interpretation. E.J. Brill Leiden. New York: Koln.

26. Said, Muhammad. (2014). Islamic Finance in Canada Problems and Prospects. Germany: Lambert Academic Publishing.

27. Satrio W, Edhi dan Syaichu, Muhammad. (2013). AnalisisPengaruhSukuBunga, Inflasi, CAR, BOPO, NPF TerhadapProfitabilitas Bank Syariah, Diponegoro Journal of Management, 2 (2), Tahun 2013.

28. Sukma, Yoli Lara. (2013). Pengaruh Dana PihakKetiga, Kecukupan Modal danResikoKreditTerhadapProfitabilitas. Prodi Akuntansi, Fakultas Ekonomi, Universitas Negeri Padang.

29. Taib, Fauziah Md., Ramayah and Razak. (2008). Factor Influencing Intention to use diminishing partnership home financing, International Journal of Islamic and Middle Eastern Finance and Management. 1 (3), pp. 235-248.

30. Taylor, J. Michael. (2003). Islamic Banking - the Feasibility of Establishing An Islamic Bank In The United State, American Business Law Journal, Winter, 40 (2), pp. 386-416.

31. Wilson, R. (1997). Islamic finance and ethical investment, International Journal of Social Economics, 24 (11), pp. 1325-1342.

32. Yamin, Sofyan dan Heri Kurniawan. (2009). SPSS Complete. SalembaEmpat: Jakarta.

33. Yuliani. (2007). Hubungan Efisiensi Operasional Dengan Kinerja Profitabilitas Pada Sektor Perbankan Yang Go Publik Di Bursa Efek Jakarta, Jurnal Manajemen \& Bisnis Sriwijaya, 5 (10). 